\title{
Post-independence African Policy: African Socialism and the Organization of African Unity
}

\author{
Asfaw Kumssa ${ }^{1} \&$ John F. Jones (Prof. Jones is now deceased) ${ }^{2}$ \\ ${ }^{1}$ United Nations Centre for Regional Development Africa Office, UN Gigiri, Nairobi, Kenya \\ ${ }^{2}$ University of Denver, Graduate School of Social Work, Denver, USA \\ Correspondence: Asfaw Kumssa, United Nations Centre for Regional Development Africa Office, UN Gigiri, P. O. \\ Box 30218, 00100 Nairobi, Kenya. E-mail: asfaw.kumssa.uncrd@undp.org; akumssa93@gmail.com
}

Received: October 8, 2014 Accepted: November 17, 2014 Online Published: November 24, 2014

doi:10.5539/par.v4n1p12 URL: http://dx.doi.org/10.5539/par.v4n1p12

The views expressed here are the authors' own and not necessarily those of the United Nations Centre for Regional Development.

\begin{abstract}
This article discusses the immediate post-independence African policy and the consequences of Africa's national sovereignty-African socialism in its various forms, and the establishment of the Organization of African Unity (OAU). The political trends in Africa in the 1940s and 1950s were largely leftist, partly as a reaction to the colonial countries that the new African leaders viewed as predominantly capitalist and an economic threat to Africa's development. After independence, several African countries embarked upon state controlled economic development policy, involving central planning and a large public sector. Right after independence Ghana, Tanzania, Zambia, Angola, Mozambique, and later Ethiopia embraced socialist ideology and embarked on centrally planned socialist development strategy. The growing appeal of Socialism and the central planning model in general, and of public enterprises in particular, arose from the recognition that the public sector is a very important instrument at the disposal of the state for the achievement of sustainable development. Moreover, nationalist African leaders embraced a state controlled development strategy because it gave them the opportunity to control private and foreign enterprises, which they viewed as agents of exploitation and domination. African nationalists were eager to bring their countries up to the socioeconomic level of other modern nations with social service systems for health, education, and welfare. However, the centralised development strategy not only hindered economic growth but also created subtle bureaucratic system that became an impediment to development. In response to this problem and encouraged by the collapse of the Soviet System and the end of the Cold War, many African countries introduced economic and political reforms that include liberalization of the economy and democratization of their polity. They have embraced the Structural Adjustment Program (SAP) and limited the role of state to the provision of some services while private initiative and ownership and role of the market are encouraged. Unfortunately, the results of the reform have not been as satisfactory as the policymakers might have wished. Social safety nets, whether traditional or government-supported, have often been dismantled. Public social programmes, such as education and health services, have slowed or ground to a halt, while at the same time unemployment or underemployment have increased because of privatization schemes and the reduction of government subsidies to state-run enterprises. While this has been a fact of life in practically all transitional economies, African countries already burdened with foreign debt had felt the pain most acutely. The problem was finding models applicable to a mainly agricultural region in contrast to the welfare systems of industrial countries. To make the choices harder, the European and North American systems differed in their social service delivery systems from those of Japan or Australia. The article also discusses the reasons for the overthrow of the various African colonies of France, Britain, and Portugal, and the eventual destruction of apartheid's white supremacy in South Africa and Namibia in the late 1900s. A number of factors contributed to the emergence of new movements in the 1980s and 1990s, notably women's civil rights. New geopolitical and economic patterns overturned much of the social policy and planning in Africa. OAU lasted for four decades, and only in 2004 was it replaced by the African Union.
\end{abstract}

Keywords: Africa, post-independence African policy, African socialism, African union, structural adjustment 


\section{programme}

\section{The Shaping of African Politics and Policies}

After independence, several African countries embarked upon state controlled economic development policy, involving central planning and a large public sector. Right after independence Ghana, Tanzania, Zambia, Angola, Mozambique, and later Ethiopia embraced socialist ideology and embarked on centrally planned socialist development strategy. The growing appeal of Socialism and the central planning model in general, and of public enterprises in particular, arose from the recognition that the public sector is a very important instrument at the disposal of the state for the achievement of sustainable development. Moreover, nationalist African leaders embraced a state controlled development strategy because it gave them the opportunity to control private and foreign enterprises, which they viewed as agents of exploitation and domination (Kumssa, 1996).

African leaders saw the colonial countries that clung on to power as predominantly capitalist. This perception may not have been entirely accurate since England in large measure and America more reluctantly were moving towards a welfare system of governance in the sense that both had in place the social safety nets to protect workers, their families, and the unemployed in an urbanized industrial economy. Historically, these were the long-term consequences of the eighteenth century industrial revolution. The British economy had experienced intermittent crises after the Second World War due to the wartime liquidation of much of Britain's overseas assets, and a lack of flexibility in management and labor practices. The Labor Party, after winning the postwar elections of 1945 and 1950, lost ground to the Conservative Party, which remained in power for the following 13 year. But while cutting back on social services the Conservatives recognized that the country's welfare system was there to stay for a population dependent on its benefits. Thus the essence of the welfare state remained intact.

For Africans, Britain's domestic politics and European models of welfare were understandably of less concern than the urgency of African nations to put their own economies in order and move forward with decolonization. The same held true for African leaders' attitude to the United States. The misery of the Great Depression had a profound impact on American society, and culminated in President Franklin D. Roosevelt's New Deal welfare policies. The federal government introduced two public assistance programs paid for with matching state-federal funds. They were Old Age Assistance that in time was superseded by the expansion of Social Security in 1950 and Aid to Dependent Children (Katz, 2010, pp. 508-529). But as might be expected, America's domestic welfare was by no means Africa's main topic of interest. In the early post-colonial period after gaining independence, most sub-Saharan African countries directed their attention aggressively to their economic and social development. Africa, like other regions of the developing world, devised its own strategies for dealing with a changing international environment. Pulled about, as it once was, by the geopolitics of the Cold War, when that thawed because of the geo-economics of a global market, African leaders favored a communitarian approach to national planning.

Nationhood was seen in terms of progress - with the aim of eventually bringing African countries to a socioeconomic level, which other modern nations enjoyed with social service systems for health, education, welfare, along with income maintenance for the poor and needy. The difficulty was finding models applicable to a mainly agricultural region in contrast to the welfare systems of industrial nations. To make the choices harder, the European and North American systems differed in their social service delivery systems from those of Japan or Australia. The public service models differed from continent to continent, and within continents. Europe's post-World War II welfare states ranged from the universalism of the Scandinavian model to more modest welfare systems of Portugal, Spain, Turkey and Greece (Lorenz, 1974). All European countries built into their legislation provision for medical and social welfare assistance, and income maintenance through insurance or public support. Indeed, decades later the 1996 Revised European Social Charter, adding to previous conventions, protocols and charters of the Council of Europe, laid down the obligations of present and future members of the European Union to provide cross-border arrangements for the health, education, and welfare of citizens -- a network of support extending from country to country throughout Europe.

\subsection{Welfare and its Multiple Expressions}

Gosta Esping-Anderson distinguishes three types of welfare capitalism: (1) Welfare states based on the principle of universalism where benefits and services belong to all citizens - in countries such as Denmark, Finland, the Netherlands, Norway and Sweden; (2) Welfare states-like Austria, Belgium, France, Germany, Spain and Italy — based on the principle of subsidiarity and preeminence of social insurance systems; and (3) Liberal regimes in Australia, Canada, Japan, Switzerland and the United States. Some countries fell outside Esping-Andersen's classification, such as Ireland, New Zealand, and the United Kingdom (Esping-Anderson, 
1990).

While the delivery of social services, however imperfect, is taken for granted in the global North, in developing countries the picture is different. In sub-Saharan Africa and much of Asia, the foundation of the social service system was built on the remnants of a colonial infrastructure (Midgley, 1995). Typical of other African colonies, the welfare system in Rhodesia (the pre-independence name of Zimbabwe) was principally designed for the benefit of the white communities. In the African communities, traditional structures provided what help was possible for vulnerable groups like the very old and the very young, but when Zimbabwe gained independence and sought to modernize, the inadequacy of the past institutional and traditional arrangements, especially in the matter of income maintenance, became apparent (Kaseke, 2003). The social exclusion in formal social security programs forced the excluded groups to rely on traditional kinship-based networks and mutual aid arrangements, which were - and remain — incapable of meeting all but the most basic needs, and often not even those.

\subsection{State-led Development Policies}

There was a noticeable socialist approach in the policy and planning of post-colonial countries. Reflecting disenchantment with Europe and the United States, the preferred models of many African governments such as Tanzania were Soviet Union and the People's Republic of China (PRC). Four countries in particular illustrate the socialist policy approach. Ghana, Zambia, Angola and Mozambique adopted centralist strategies with mixed results (Osie-Hwedie \& Osie-Hwedie, 2000, pp. 226-251). In Ghana the government of Nkrumah, from 1961 to 1966, followed a socialist strategy with state ownership of industry and land. Based on a centralized economy, the Ghanaian government offered free or largely free primary, secondary and tertiary education, as well as other subsidized social services. Zambia also, from 1964 to 1982, had a semi-socialist economy based on centralized planning with capital-intensive import substitution industries, to the neglect of agriculture. When Angola achieved independence in 1975, the government embraced a socialist development strategy with the collectivization of agriculture and partial nationalization of industry, except for the oil industry. Around the same time, Mozambique in its post-independence fervor adopted a plan that involved the government nationalizing assets in land (through state farms), banking, industry, healthcare, education, and housing. This pattern of socialism, frequently under heavy authoritarian rule, was repeated over and over again, with different timing and degrees of authoritarianism in other sub-Saharan nations, such as Tanzania with its Socialist and Self-Reliance Principles outlined in the Arusha Declaration. But the romance with socialism was about to change.

\subsection{Discontent with Socialism and Structural Adjustment}

In the 1980s new geopolitical and economic patterns overturned much of the socialist policy and planning in Africa and the tide had turned. Privatization of public enterprises and liberalization of the economy were unleashed in Africa as an attempt in search of an alternative development paradigm. The collapse of the central planning system in the former Eastern bloc countries and the economic crisis of Africa have both fostered a mood that has become increasingly hostile to the public sector and state intervention in the economy. Some economists and policy makers had raised questions about the effectiveness of public enterprises and their economic performance, arguing that public enterprises have not only failed to produce the required surplus to finance their operations, but that the state subsidies spent to maintain their activities have become a drain on government treasuries. It is argued that the centralised development strategy not only hindered economic growth but also created subtle bureaucratic system that became an impediment to development (Jones and Kumssa, 2000). In response to this problem and encouraged by the collapse of the Soviet System and the end of the Cold War, Ethiopia, Tanzania, Angola, and Mozambique introduced economic and political reforms that include liberalisation of the economy and democratisation of their polity. They have embraced the Structural Adjustment Program (SAP) and limited the role of state to the provision of some services while private initiative and ownership and role of the market are encouraged. Some African countries such as Ethiopia, Uganda, Ghana, Namibia and others have also embarked upon decentralisation and devolution of power to regional and local authorities to empower local and regional communities. The precipitating events were the collapse of communism in Eastern Europe, the introduction of a free market in Asian socialist economies, as well as the failure of statism and dictatorial authority in many African countries. Another important factor accounting for the abandonment of central planning was the introduction of structural adjustment programs (SAP), whether orchestrated from within or imposed from without by the World Bank and the International Monetary Fund (IMF). SAP, which emerged in 1980s and anchored on a liberal economic philosophy, aimed at reducing or removing external and internal imbalances and bringing long-term structural changes in the economy through institutional reforms that would guarantee sustainable growth. These economic improvements were believed to be induced through the SAP's policy prescription such as exchange rate adjustment, pricing policies and fiscal reforms. Almost two-decades after SAP was launched in Africa, it had not generated the desired sustainable 
development. On the contrary poverty and income inequality appeared to be spreading in Africa. In many African countries, where Structural Adjustment Program (SAP), was introduced as part of the reform policy, economic growth had increased. However, economic growth had been accompanied by rising unemployment rate, poverty, growing income and social inequality. For instance, Ghana (which was considered to be a success story of a country that implemented SAP) has achieved an economic growth rate of 8.7 percent in 1985 . However, when considering the population growth rate, no positive conclusion could be drawn. The reform in Ghana had hit hard the rural households, low-income urban households and children under 5 years of age. Similarly, in Zimbabwe, which began implementing SAP in 1991, increased maternal mortality rates were noted because of the introduction of hospital fees for those earning more than four-hundred Zimbabwean dollars and above per month (Kumssa, 2006; Kaseke, 2003). In the developing world, structural adjustment meant an acceptance of neoclassical theory that sought to make both the state and the market more efficient, thereby accelerating growth and eliminating waste. The goal of neoclassical theory was to make the market the engine that would drive economic development. Individual initiative and unfettered control of the market would consign to the state no more than a supportive role in development (Rapley, 2007). In practice that called for the privatization of state-run programs, fiscal austerity and retrenchment, trade liberalization, deregulation, and currency devaluation. But the transition to a market orientation had a downside for many, perhaps most, emerging economies.

When structural adjustment was introduced in sub-Saharan Africa as part of socioeconomic reform, the economic growth that occurred was often at the cost of rising urban unemployment, increased rural poverty, as well as greater social and economic inequality (Jones, 2009, pp. 93-95). Zambia, which began implementing its structural adjustment program in 1991, saw access of the poor to medical services limited with the introduction of hospital fees necessitated by the withdrawal of government subsidies. Ghana, which at first achieved an impressive economic growth rate after its commitment to socioeconomic reform along IMF lines, had its financial gains offset by the establishment of user fees in healthcare and education which made these services too costly for the poor. Government expenditures on the social services fell far below the demands of Ghana's growing population.

The structural adjustment program aimed at reducing or eliminating external and internal imbalances through radical economic reforms. Zambia espoused such an agenda in its Economic and Financial Policy Framework Paper in 1987, along with a Public Sector Investment Program devised by the World Bank and the IMF. Zimbabwe adopted a five-year Economic Structural Adjustment Program to stave off an economic crisis. Other countries did the same sort of thing, hoping that the prescriptions of exchange rate adjustment, pricing policies and fiscal reforms would bring with them sustainable development.

The reform policies had the harshest consequences for vulnerable groups, including women and children, the elderly and the sick, and indeed for a broad sweep of working people, such as laborers on commercial farms and subsistence farmers. The effects on health services in a region brought to its knees by diseases like malaria were catastrophic. Jeffrey Sachs' sardonic comment that the main IMF prescriptions to tighten belts for patients too poor to own belts has special relevance to Africa's situation. The austerity resulting from IMF recommendations frequently led to riots, coups, and the collapse of public services, but blame was usually laid at the door of governments for ineptitude rather than where it rightly belonged in the first place-ill conceived economic policy (Sachs, 2005).

The stern measures of these structural reforms were justified on the grounds of future economic gains, offering projections of a 3 percent increase in Africa's gross domestic product (GDP) by 2000. For four consecutive years in the 1990s, GDP in Africa did in fact grow faster than population, contrasting markedly with a previous decade-and-a-half of declining per capita income. By the end of the decade, a 3.3 percent growth in Africa's GDP, compared with 2.9 percent growth in 1997, supported the argument in favor of economic reform. This hope found further support in an optimistic report of the United Nations Economic Commission for Africa (UNECA), which reviewing past performance, concluded that the region could reduce extreme poverty substantially in the years ahead (UNECA, 1999).

This positive aggregate economic performance, however, was not shared evenly across the continent. In reality, growth was recorded only in the north and central African sub-regions, while the growth rate declined in the eastern, western and southern sub-regions. The five largest economies of the continent-South Africa, Nigeria, Algeria, Egypt and Morocco - accounted for roughly 37 percent of the population, and 59 percent of gross domestic product. The 11 oil-exporting countries of Algeria, Egypt, Libya, Tunisia, Ivory Coast, Nigeria, Cameroon, Gabon, Republic of Congo, Angola and Equatorial Guinea shared this economic prosperity. The 33 least developed countries, with 45 percent of the population, had just 17 percent of GDP. The United Nations 
Development Programme (UNDP) in its 2005 annual human development report painted a far gloomier picture than UNECA's projection (UNDP, 2005) . While in most countries UNDP's human development index (HDI) - a composite indicator measuring income, education and health-marked improvement over a decade, the exception was sub-Saharan Africa along with six countries in the former Soviet Union.

More than a third of sub-Saharan Africa's population registered lower scores on the UNDP's human development index in 2003 than in 1990. The countries included Botswana, Cameroon, Central African Republic, Congo, and Democratic Republic of the Congo, Ivory Coast, Kenya, Lesotho, South Africa, Swaziland, Tanzania, Zambia, and Zimbabwe. As the United Nations Development Programme's 2005 human development report suggests, the combination of the spread of HIV/AIDS, economic stagnation or reversal, and the slow progress of education were telling factors in the decline (UNDP, 2005). For example, patients with HIV-related illness took up more than half of all hospital beds in Ivory Coast and Uganda. The human resources cost of the pandemic showed in the loss of two-thirds of Zambia's teachers to HIV/AIDS. The economic stagnation in sub-Saharan Africa had the most serious consequences for the poor and vulnerable, with households in Uganda and Namibia selling food and livestock to cover medical expenses.

\section{Organization of Africa Unity (OAU)}

The independence movement demanded a political and economic organization even more than an ideology, such as socialism, to advance its goals. Structural adjustment and other short-term reforms were weakening sub-Saharan Africa. Needed was some organization capable of to rallying a continent to resist Western intrusion. The establishment of the Organization of African Unity (OAU) was discussed at a meeting in Casablanca, Morocco (1961), and then in Dar-Es-Salaam, Tanzania (1974). While the Dar-Es-Salaam Congress, hosted by Julius Nyerere, then-President of Tanzania, drew participants from the diaspora, the main emphasis was on Africa's national concerns. Although unsure of the worldwide implications of Pan-Africanism, plans went ahead for an institution that would promote independence and continental unity.

There was, however, a division among African countries as to how fast and to what extent African unity should go. One group of mainly francophone countries known as the Brazzaville Group-named after the capital of Congo-Brazzaville - advocated a minimalist approach that favored the coordination of national economic policies through customary diplomacy rather than the creation of continent-wide institutions (Schraeder, 2004, pp. 253-254). Another camp, a Ghana-Guinea-Mali Union and later joined by Egypt, Algeria and Morocco, called the Casablanca Group, pushed for immediate and complete unity. Still another group of 24 nations including Nigeria, Liberia, Senegal, Ivory Coast, Cameroon and Togo — named the Monrovia Group-were for a more gradual approach, rejecting the idea of a political union as impractical, given the newfound independence of sovereign states. Yet the opposing groups were able to overcome their differences when it came to drafting the charter of the Organization of African Unity in 1963 (OAU, 1963). The following year marked its inauguration in Addis Ababa, Ethiopia, a proud moment for Africa when its leaders once more proclaimed their commitment to a unified continent while emphasizing the sovereignty of African nations.

The inauguration of the Organization of Africa Unity (OAU) began a consolidation of African unity that was to last for four decades. While not disavowing a world oriented Pan-Africa, its founders were concerned first and foremost with the decolonization of other African countries. Largely for political reasons, the emphasis was on the establishment of African sovereign states rather than a close embrace of the diaspora. Furthermore, the movement's leaders were suspicious of foreign interference, and resented the impact of globalization on Africa's development.

The Organization of African Unity (OAU) could claim much of the credit for the decolonization of many African states. Having fought so vigorously for sovereign statehood, the new rulers were intent on preserving it. But sovereignty had its downside in that it too easily slid into despotic ways. Two notable heroes of African independence, Ghana's Kwame Nkrumah and Zimbabwe's Robert Mugabe, were among African heads of state that copied the behavior of colonial rule in favoring centralized governance and disregarding civil rights. The colonial state was a despotic institution where law was an unrestrained instrument of force, authorized by administrative fiat (Shijvi, 2004, pp. 155-206). But as president of Ghana, when Nkrumah found his position threatened he did not hesitate to use the law for his own purposes. In 1958, for instance, he wrote the Preventive Detention Act that made it possible for his administration to arrest and detain anyone charged with treason without due process of law. Mugabe's tyrannical rule in time alienated his early supporters in the Organization of African Unity.

Corruption and economic mismanagement characterized many of the newly independent countries (Murithi, 2007, pp. 150-153). For some government leaders despotism offered a way of controlling their country through 
an over-centralized administration along the lines of their colonial predecessors. The prospect of increased power and financial gain was a strong incentive for narrowing the circle of control. The introduction and spread of political elites marked the postcolonial African environment. While tribes and clans deemed useful to those in power benefitted, large populations of the newly independent states remained abjectly poor. The consequences were civic disruption and violence, evident even today in the variations in national levels of development and wealth, and the prevalence of economic strategies and resources that some ethnic clusters and local communities use to compete against other groups or parties, all to the detriment of national unity according to the United Nations Development Programme (UNDP, 2004). Just as states can seek citizen cooperation on the grounds of national origin, so too have families, villages, and tribes utilized their community social bonds to assert their own common rights and to make claims against each other (Alila, 2001, pp. 29-57). Certainly the inheritance of a faulty and artificial state structure in many African nations was an impediment to peaceful economic development. But to blame all national violence and bad governance on the colonial era and its consequent administrative institutions is at best an overstatement that ignores the complexities of old and new Africa. To attribute the ongoing problems of poverty and civil discord to a single cause would be disingenuous.

\section{Democracy and the Competing Models of Socialism}

Linking socialism and democracy in Africa, Charles Andrain makes the point that African democracy invoked an idealized village and tribal system where custom, acting as a sort of unwritten constitution, limited arbitrary political power, making traditional African life by its very nature socialistic (Andrain, 1964, pp. 156-183). In this markedly idealistic theory individuals lived in harmony with other members of the group, bound by a collective concern for immediate family, extended family, clan and tribe. There were no classes in the economic sphere based on capital accumulation, although there were social classes founded on functional differentiation - whether as warriors, elders, ritual healers, or herders. All property was held in common by family or village. Communal landowning and land cultivation was in fact commonplace in many parts of Africa. In the struggle for independence, African leaders appealed to the memory of pre-colonial states like Mali, Ghana and Senegal. African who first resisted European intrusion-Almamy Samory, El Hadj Omar, Chaka Zulu - were seen as heroic freedom fighters and models to be imitated.

In the minds of many African leaders in the immediate postcolonial years democracy could not take root on the continent without a socialist society. Democracy was not simply a method or technique of governance; it was a way of achieving the goals of socialism. Not just that. African socialism was based on a philosophy of non-violence. Free of conflict, the movement was to be a struggle against economic poverty and injustice. Political command of the economy combined with communal ownership of land constituted the chief means of securing a socialist society. Where others saw a disparity between democracy and socialism, the dominant desire for African independence demanded a tight supervision of the political process, rather than competition among groups. As President Nkrumah made clear when the Ghana became a republic, party membership - in Ghana's case through the Convention of the People's Party - took precedence over parliamentary membership, and could not be challenged (Nkrumah, 1961, p. 209).

The theory of African democracy was markedly different from both Western parliamentary democracy_assumed to be a form of bourgeois capitalism-and traditional Marxism-Leninism. In English-speaking Africa, strategies were pragmatic, less concerned with theory than putting an end to colonialism. The French intellectual tradition was more evident in politicians like Léopold Senghor, Mamadou Dia, and Guinea's President Sékou Touré. Attention to the finer points of theory was especially pronounced in the extensive writing of Touré who borrowed heavily from the theory of Karl Marx. What attracted him especially was Marx's insistence that the thought and action of a party should be united; that social values should determine economic strategies rather than the other way around. Touré shared Marx's impatience and anger with the contradictions of the economic status quo. But while the politician in Sékou Touré was drawn to the organizational principles of Marxism, he was less dedicated to class conflict than Marx. As might be expected of an African leader embroiled in the independence movement, Touré's fixed his sight on Arica's political situation. Not capitalizing on class or economic contradictions, he largely denied the importance of class in Africa's struggle (Jumba-Masagazi, 1970, p. 10).

There was no single model of democracy among African leaders. While African democracy differed from Western notions of government in its concept and spirit, Nkrumah revealed his own ambiguity in his comments on Ghana's traditional tribal democracy when he declared that "Africa would in time doubtless evolve forms of government rather different from the traditional western pattern but no less democratic in their protection of the individual and his inalienable rights."(Nkrumah, 1961, p. 158). The comment is vague enough to cover all interpretations of African political, social and economic civil rights. While seeking more precision, Andrain in 
his article "Democracy and Socialism" also warns against the danger of defining African democracy too narrowly:

Despite this unanimous verbal attachment to African democracy, African leaders have formulated three somewhat different ideological interpretations of a democratic society. Sékou Touré, Kwame Nkrumah, and Julius Nyerere express a monistic interpretation. A second theory, best stated by Nigerian leaders, is based on a pluralistic model, in which larger institutionalized groups compete for influence. A third model, a variant of the pluralistic interpretation, expresses the individualistic revolt against racial groupism in East, Central, and South Africa. Most explicitly defined by Albert Luthuli of South Africa and Tom Mboya of Kenya, this theory stress individual rather than group, rights. (Andrain, 1964, p. 157)

For the political leaders of the newly independent states, socialism was readily associated with the concept of democracy. The term "African socialism" simultaneously implied anti-colonialism, independence, economic growth, poverty alleviation, and Pan-Africanism. It had no clear-cut definition because of its very newness, though it drew on past community profiles, both mythical and real. It did not resemble nineteenth century European models - the orthodox socialism of Marxists, anarchists or guild socialists-lacking a unified theory found in the doctrinaire exposition of Das Kapital, for instance. In attempts to describe a movement closer to African tradition and culture, the competing explanations of African socialism appeared in three different approaches.

\subsection{The Monistic Model}

The monistic, populist concept of democracy emphasized the values of popular sovereignty and political equality. As portrayed by Andrain, the clearest exemplars of the monistic or populist concept of democracy were Sékou Touré, Kwame Nkrumah, and Julius Nyerere. For Touré as Guinea's president, the interests of the more general took precedence over the particular interests. He argued for a unity of purpose where Africans in all sectors of life shared a common interest. In his view, the interests of the family came first, then the village, district, and nation. He initially attempted to put in place an economic and political system with a large degree of central government control, exercised by a single party, the Parti Démocratique de Guinée (PDG) to ensure the supremacy of the common good, as he saw it. But ensuring uniformity, for all its idealism, came at the price of sacrificing, if need be, the individual for the benefit of the community. His regime was responsible for large-scale arrests and even the execution of those who opposed government policy. He equated liberalism with compromise, anarchy, and the dominance of individual and group interests. In a 1942 statement of Guiney's policy, The International Policy of the Democratic Party, Touré justified autocratic rule when challenged, even involving forced labor. As he stated:

The enemy of revolutionary firmness is liberalism, which from compromise to compromise drives a party into incriminations and anarchy. The best arrangements and most clever compromises only lead to general discontent and could not possibly preserve the higher interests of the people since they subordinate them, wholly or partly, to the selfish interests of groups or individuals; they could only maintain inequalities and increase antagonisms. (Touré, 1942, pp. 219-220).

However, he was ready to compromise when, following French withdrawal, economic development slowed in Guinea. Tight state control lessened in the early 1960s, aided by rapprochement with France in the 1970s. But the damage was done (Hakim \& Sherwood, 2003, pp. 179-180). Touré was seen more and more as an autocratic leader ruling over an impoverished, corrupt and repressive one-party state. His radical Pan-Africanism had long been abandoned. He formed alliances with some of the continent's most reactionary leaders. As a result Pan-Africanists who expected more of a liberated land were acutely disappointed.

Kwame Nkrumah also believed that European socialism arose from a particular set of circumstance not found in Africa - the exploitation of one socio-economic class by another (Jumba-Masagazi, 1970, p. 15). Europe's social stratification was, from the monistic viewpoint, a consequence of the industrial revolution, while Africa was egalitarian, a cultural characteristic of African society. As Nkrumah declared in his autobiography, traditional African society was marked by its low degree of stratification with few distinct classes. At its core, African society was founded on an extended family system that, in turn, expanded into kinship groups that further extended into clan systems. In his Autobiography Nkrumah stated that communalism reflected original African values of man imposes on everyone duties of a socialist kind:

Herein lies the theoretical basis of African communalism. The theoretical basis expressed itself in the social level in terms of institutions such as the clan, underlining the initial equality of all and the responsibility of many for one. In this social situation, it was impossible for classes of a Marxian kind 
to arise. By a Marxian kind of society, I mean one which has a place in a horizontal social stratification. Here classes are arranged in such a way that there is a disproportion of economic and political power between them. In such a society there exist classes, which are crushed, lacerated and ground down by the encumbrance of exploitation. In this sense, there are no classes in traditional African society. ( $\mathrm{p}$. 132)

The classlessness of traditional African society was asserted over and over again in monistic intellectual circles, as opposed to a Marxian interpretation of history. African socialist leaders shunned the idea of social class, and rejected orthodox Marxism as a European import. The concept of African socialism is quite possibly African in origin, as the Kenyan government asserted. "No class problem arose in the traditional African society and none exists today among Africans. The class problem in Africa, therefore, is largely one of prevention ..." (Kenya, 1965, p. 56). African socialism was a term describing the African political and economic system that was positively African, not imported from any country or a blueprint of any foreign ideology. The sharp class divisions that existed in Europe had therefore no place in African socialism and no parallel in African society.

Nkrumah represented this philosophy in his book, Consciencism, where he states, "The traditional face of Africa includes the attitude towards man which can only be described, in the social manifestation, as being socialist. This arises from the fact that man is with a certain inward dignity, integrity and value." (Nkrumah, 1964, p. 122). The fundamental goal of this type of socialism was the attainment of a just and egalitarian society where there was no exploitation. The goal was not merely to fight for higher wages or wage against the many social ills such as corruption, racialism, exploitation, or tyranny. The purpose was wider in striving for a just, co-operative and classless society (Ogot, 1964). Regardless whether such a Utopia is even possible, Nkrumah failed in his ambition to achieve it. As a consequence of economic problems within Ghana, and continued interference by Britain and the United States, his hold on power faded. An increasingly corrupt and dictatorial government sapped his popularity. When in 1961 bomb attacks heightened civil unrest, and a number of assignation attempts threatened his life, Nkrumah took an increasingly harder line. In 1964 he banned opposition parties and declared a one-party state. Overthrown by a military coup, he went into exile in Guinea where Sékou Touré made him co-president. Despite his efforts to rally the citizens of Ghana to overthrow the military regime, he failed and died in exile.

It is hard to escape the impression of nostalgia in the manner in which the advocates of socialism harked back to traditional tribalism when reaching for examples of true African socialism before the advent of colonialism (Kakonge, 1964). When Julius Nyerere introduced a collective policy in Tanzania's agricultural system, he used the term Ujamaa - a Swahili word equivalent to extended family or familyhood - to describe African socialism. It was, in his view, opposed it to capitalism, which sought to build a happy society built on the exploitation of man by man but equally opposed to doctrinaire socialism with its assumption of inevitable conflict. In his Ujamaa - Essays on Socialism Nyerere (1968) wrote:

We, in Africa, have no more need of being 'converted' to socialism than we have of being 'taught' democracy. We are rooted in our own past-in the traditional society, which produced us. Modern African socialism can draw from its traditional heritage the recognition of 'society' as an extension of the basic family unit. But we can no longer confine the idea of the social family within the limits of the tribe, nor, indeed, of the nation. For no true African socialist can look at a line drawn on a map and say, 'The people on this side of that line are my brothers, but those who happen to live in the other side of it can have no claim on me'; every individual on this continent is his brother.

It was in the struggle to break the grip of colonialism that we learnt the need for unity. We came to recognize the same socialist attitude of mind which, in the tribal day, gave to every individual the security that comes of belonging to a widely extended family, must be preserved within the still wider society of the nation. Our recognition of the family to which we all belong must be extended yet further - beyond the tribe, the community, the nation, and even the continent- to embrace the whole society of mankind. This is the only logical conclusion for true socialism. (p. 12)

\subsection{The Pluralistic Model}

The pluralists, in contrast to Touré, Nkrumah, and Nyerere, saw democracy as a framework within which institutionalized groups competed for power. Among the pluralist politicians were President Leopold Senghor of Senegal and Mamadou Dia also of Senegal, Ivory Coast's President Houphouët-Biohny, and Nigeria's Chief Obafemi Awolowo. As a check on majority or minority-group tyranny, pluralists put their faith in intermediary associations - between government and the populace - to preserve liberty. Both Senghor and Dia (Senghor's former Prime Minister) shared the opinion that "African communalism rejects communistic violence and prefers 
to reconcile differences through mutual consultation and co-operation. Rather than following the examples of either communism or capitalism, both of which curtail freedom of thought and art. African socialists must encourage the expression of a socialist humanism, sensitive to original African conditions, a humanism safeguarding human spontaneity and traditional cultural values." (Andrain, 1964, p. 181). Africa (now the Republic of Benin) and the Ivory Coast, which were attempting to construct democracy based on traditional diversity. In the case of Dahomey, the governing Parti Dahoméen de l'Unite was a coalition of two regional-religious factions: the northern Muslim wing and the southern Catholic wing. Mamadou Dia saw this sort of cooperation as a spiritual humanism in harmony with both the Christian and Muslim way of life - a value fully compatible with African socialism. Such peaceful socialism was not, in his view, a scholastic theory but a vital challenge and hence also an ethnic and obligation (Jumba-Masagazi, 1970, p.17).

Immediately following the Second World War, Chief Obafemi Awolowo in Nigeria proposed a federal system whereby each state in the Nigerian federal union should contain a separate ethnic group. In his autobiography, Awolowo (1960) explained his rational for federalism. The three Nigerian leaders-Obafemi Awolowo of the Western Region, Nnamdi Azikwe of the East, and Tafawa Balewa of the North - all argued for a communal model of democracy. For Awolowo, democracy depended on a system of checks and balances necessary to prevent a monopoly of power. In his autobiography, Awolowo explained his rational for federalism:

Whenever there are two or more persons, divergence of opinion is bound to exist....The people are entitled as of right to be given the chance to examine all sides of the problems confronting them, before expressing their majority will at the polls. Such an examination, however, will be possible only where people who hold different shades of opinions are allowed to organize themselves into parties if they wish, and are also free to explain their respective points of view to the electorate .... (Awolowo, 1960, p. 304).

\subsection{The Individualistic Model}

When Charles Andrain constructed and published his research on the individualist model in the 1960s, the two countries he chose as exemplars of the model were South Africa and Kenya. But these countries were experiencing political and racial turmoil and continued to do so for decades. The principal authors cited by Andrain were Albert Luthuli of South Africa (Luthuli, 1962) and Tom Mboya of Kenya (Mboya, 1956, p. 37). While both authors were eloquent advocates for a peaceful multiracialism, it was not until 1994 that South Africa abolished apartheid and gained true liberation. In 1961, in the wake of a whites-only referendum, the country became a commonwealth. At that point a State President replaced Queen Elizabeth II as head of state. Racial segregation or apartheid, begun under Dutch and British rule, continued unabated with the Nationalist Government classifying all peoples into three races, and legislating the rights and obligations of the separate and unequal populations. Despite international sanctions and growing unrest within the country, the government oppressed resistance to its policies harshly. Violence spread with anti-apartheid rallies, marches, strikes, and bombings. Ultimately, pressure had so increased on the white political leaders, that F.W. de Klerk negotiated with Nelson Mandela in 1993, and a transition in government was finalized in 1994.

Kenya did not gain independence till 1963. It was still struggling with political and racial rivalries, and had yet to find a stable direction. Jomo Kenyatta of the Kikuya tribe, who had previously been imprisoned and exiled on suspicion of leading the Mau Mau insurgency, became the country's first president upon the adoption of a republican form of government, and shortly after formed a coalition of two opposing parties - the Kenya African National Union (KANU) and the Kenya African Democratic Union (KADU). However, a new opposition party was formed - the Kenya People's Party (KPP) - in 1966 under the leadership of the leftist Jaramogi Oginga Odinga that resulted in further party disunity. Eventually after further political strife and the death of Kenyatta, Deniel arap Moi, a member of the small Kalenjin ethnic tribe, was declared president in 1978 for a five-year term. Only in the 1990s did a semblance of stability appear; the country continued to be plagued with racial discord.

Given the uneven opportunity for assessing the usefulness of Andrain's individualist model in South Africa and Kenya, its adoption might benefit from further research on the applicability of this model to other countries in the sub-Saharan region. But despite the inadequacy of the individualist model, the superiority of Andrain typology over Esping-Andersen's description of Western welfare systems is its predominantly African context.

\section{From the Organization of African Unity to the African Union}

Headquartered in Addis Ababa, Ethiopia, the Organization of African Unity was founded to bring African nations together and strengthen their independence from European rulers. While OAU firmly opposed dictatorial colonial rule, the new leaders fell into the authoritarian trap in their embrace of socialism. The justification was 
the sovereignty of the newly independent states, and it resulted in the 1960s in the growing practice of national autonomous development. The movement was linked to a socialist commitment, most clearly stated by Julius Nyerere in the Arusha Declaration. The unquestioned acceptance of states' autonomy was part and parcel of a heavily authoritarian philosophy (Nyerere, 1967). While intensely nationalistic and democratic in tone, the Arusha philosophy was paradoxically a blow to civil society and the popular participation of citizens. Its outcome was top-down administration in those countries that adopted socialism as their guiding principle. National sovereignty explains the Organization's opposition to any armed intervention against any member state (OAU, 1963, May 25). Article 3 spelled out seven principles prohibiting any kind of aggressive action against state sovereignty:

1) The sovereign equality of all Member States.

2) Non-interference in the internal affairs of States.

3) Respect for the sovereignty and territorial integrity of each States and for its inalienable right to independent existence.

4) Peaceful settlement of disputes by negotiation, mediation, conciliation or arbitration.

5) Unreserved condemnation, in all its forms, of political assassination as well as of subversive activities on the part of neighboring States or any other States.

6) Absolute dedication to the total emancipation of the African territories which are still dependent.

7) Affirmation of a policy of non-alignment with regard to all blocs.

This statement of policy by the Organization of African Unity was aggressive in its rejection of all intervention by other states, including and especially military force. This assertion had the backing of OAU's political leaders when it was written, but popular support was another matter, and by the 1980s and 1990s the burden and indignity of autocratic governance was widely unpopular, and the tide had turned. There were calls for alternatives ways of governing and being governed. The discontent had institutional consequences, and took the form of a new continental association in 2004 when the African Union was established.

\section{Conclusion}

The political trends in Africa in the 1940s and 1950s were largely leftist, partly as a reaction to the colonial countries that the new African leaders viewed as predominantly capitalist and an economic threat to Africa's development. Therefore, they embarked upon Socialist ideology and state controlled economic development policy, involving central planning and a large public sector. However, the centralized development strategy not only hindered economic growth but also created subtle bureaucratic system that became an impediment to development. In response to this problem and encouraged by the collapse of the Soviet System and the end of the Cold War, many African countries introduced economic and political reforms that include liberalisation of the economy and democratisation of their polity. They have embraced the Structural Adjustment Program (SAP) and limited the role of state to the provision of some services while private initiative and ownership and role of the market are encouraged. Unfortunately, the results of the reform have not been as satisfactory as the policymakers might have wished. Social safety nets, whether traditional or government-supported, have often been dismantled. Public social programmes, such as education and health services, have slowed or ground to a halt, while at the same time unemployment or underemployment have increased because of privatization schemes and the reduction of government subsidies to state-run enterprises. While this has been a fact of life in practically all transitional economies, African countries already burdened with foreign debt had felt the pain most acutely. The reform policies have hit hard on the poor, fueling wide spread poverty and unemployment. Particularly, the programme had adversely affected the social sector of the economy. Because of the government austerity measures, the health and education sectors had been crippled. The inflation, triggered by the appreciation of local currencies, had reduced the real income of the poor and the vulnerable groups, particularly the laborers who work on the commercial farms and the subsistence farmers. Consequently, the SAP was abandoned and many Africa countries began pursuing a policy of "sustained growth with equity" (World Bank, 1995: 2).

African nationalists were eager to bring their countries up to the socioeconomic level of other modern nations with social service systems for health, education, and welfare. The problem was finding models applicable to a mainly agricultural region in contrast to the welfare systems of industrial countries. To make the choices harder, the European and North American systems differed in their social service delivery systems from those of Japan or Australia.

A number of factors contributed to the emergence of new movements in the 1980s and 1990s, notably the 
collapse of the Soviet System, the concern for environmental issues, women's civil rights, etc. New geopolitical and economic patterns overturned much of the social policy and planning in Africa. OAU lasted for four decades, and only in 2004 was it replaced by the African Union.

\section{References}

Alila, P. O. (2011). Local communities, social systems, and human security. In A. Kumssa, H. W. Williams, \& J. F. Jones (Eds.), Conflict and human security in Africa: Kenya in perspective. New York: Palgrave Macmillan.

Andrain, C. F. (1964). Democracy and socialism: Ideologies of African leaders. In D. E. Apter (Ed.), Ideology and discontent. London: Free Press of Glancoe.

Awolowo, O. (1960). Awo: The autobiography of Chief Obafemi Awolowo. Cambridge, UK: Cambridge University Press.

Constitutive Act of the African Union. Adopted by African Heads of State and Government in Lomé, Togo, in July 11, 2000, effective May 26, 2001.

Esping-Andersen, G. (1990). The three worlds of welfare capitalism. Cambridge, NJ: Princeton University Press.

Hakim, A., \& Sherwood, M. (2003). Pan-Africa history: Political figures from Africa and the diaspora since 1787. New York: Routledge.

Jones, J. F. (2009). Liberty to live: Human security and development. New York: Nova Science Publishers.

Jones, J. F., \& Kumssa, A. (Eds.). (2000). The Cost of Reform: The Social Aspect of Transitional Economies. New York: Nova Science Publishers, Inc.

Jumba-Masagazi, A. H. K. (Ed.). (1970, September). African Socialism: A Bibliography and Short Summary. Nairobi: The East African Academic Research Information Circular.

Kakonge, J. (1964, April). Scientific socialism in Africa. East Africa Journal, 1(1), 6-9.

Kaseke, E. (2003). Social exclusion and social security: The case of Zimbabwe. The Journal of Social Development in Africa, 18(1), 33-48. http://dx.doi.org/10.4314/jsda.v18i1.23818

Katz, M. B. (2010, October). The American welfare state and social contract in hard times. Journal of Policy History, 22(4), 508-529. http://dx.doi.org/10.1017/S0898030610000242

Kenya. (1965). African socialism and its application to planning in Kenya. Nairobi: Government Printer.

Kumssa, A. (1996). The Political Economy of Privatization in Africa. International Review of Administrative Sciences, 62(1), 75-87. http://dx.doi.org/10.1177/002085239606200105

Kumssa, A. (2006). Globalization and Structural Adjustment Programme. Unpublished Manuscript. Nairobi, Kenya.

Lorenz, L. (1974). Social work in a changing Europe. London \& New York: Routledge.

Luthuli, A. (1962). Let my people go: An autobiography. Johannesburg and London: Collins.

Mboya, T. (1956). The Kenya question: An African answer. Fabian Tract No. 302. London.

Midgley, J. (1995). Social development: The developmental perspective in social welfare London, Thousand Oaks, CA, \& New Delhi: Sage.

Murithi, T. (2005). The African Union: Pan-Africanism, peacebuilding, \& development. Aldershot, UK \& Burlington, VT: Ashgate.

Nkrumah, K. (1957). The autobiography of Kwame Nkrumah. Edinburg \& New York: Nelson.

Nkrumah, K. (1961). I speak of freedom: A statement of Africa ideology. New York: Praeger.

Nkrumah, K. (1964). Consciencism: Philosophy and ideology for decolonization and development with particular reference to the African revolution. London: Heinemann.

Nyerere, J. K. (1967). The Arusha declaration and TANU's policy of socialism and self-reliance. Dar-es-Salaam, Tanzania, 1967. Written for Tanganyika African National Union (TANU).

OAU. (1963, May 25). Charter of the Organization of African Unity. Adopted by the Heads of African States and Governments in Addis Ababa, Ethiopia.

Ogot, B. A. (1964, April). Diviationism is inherent. East Africa Journal, 1(1), 2-6. 
Osie-Hwedie, K., \& Osie-Hwedie, B. Z. (2000). Structural adjustment and social service provision: Lessons from four African countries. In J. F. Jones, \& A. Kumssa (Eds.), The cost of reform: The social aspect of transitional economies. New York: Nova Science.

Rapley, J. (2007). Understanding development: Theory and practice in the third world (3rd ed.). Boulder, CO: Lynne Rienner.

Sachs, J. (2005). The end of poverty: Economic possibilities of our time. New York: Penguin.

Shivji, I.G. (2008). Revisiting the debate on national autonomous development. In S, Adejumobi, \& A. Olukoshi (Eds.), The African Union and new strategies for development in Africa (pp. 177-206). Amherst, New York: Cambria Press.

Touré, S. (1942). The international policy of the Democratic Party of Guiney. Cairo.

Touré, S. (1959). Toward full re-Africanization: Policy and principles of the Guiney Democratic Party. Paris.

UNDP. (2004). Human development report, 2004: Cultural liberty in today's diverse world. New York: Oxford University Press.

UNDP. (2005). Human development report 2005. New York \& Oxford: UNDP and Oxford University Press.

UNECA. (1999). Economic report on Africa: The challenges of poverty reduction and sustainability. Addis Abba: UNECA.

World Bank. (1995). A Continent in transition: Sub-Saharan Africa in the mid-1990s. Washington, DC: The World Bank.

\section{Copyrights}

Copyright for this article is retained by the author(s), with first publication rights granted to the journal.

This is an open-access article distributed under the terms and conditions of the Creative Commons Attribution license (http://creativecommons.org/licenses/by/3.0/). 